\title{
Game Model Based on Cultural Values Approach in Developing Interpersonal and Kinesthetic Intelligences in Early Childhood
}

\author{
Hanafiah, Reni Nurapriani, M. Andriana Gaffar \\ Nusantara Islamic University, Bandung, Indonesia \\ e-mail: hanafiah@fkip-uninus.ac.id
}

\begin{abstract}
The research focused on the development of early childhood through the use of game which based on cultural values. The selection of games based on local culture of Sundanese is based on the facts that many games that are not appropriate for early childhood today, which not only makes the decline in awareness to maintain and preserve cultural values, especially traditional culture of West Java, but also affect the development of intelligence child. In the first year of this research has produced a conceptual model of learning interpersonal and kinesthetic intelligence based on the local culture of Sundanese with the outcome of a textbook material. Referring to the first year results and Uninus Research Master Plan, the second year's achievement plan is to produce an empirical model of early childhood interpersonal and kinesthetic intelligence learning based on Sundanese local culture with outcomes generating articles published in reputable international journals and textbooks for kindergarten. The results show that the local-based Sundanese cultural game model is able to optimize ienterpersonal intelligence and early childhood kinesthetic intelligence. This model is applied through the Sondah game, stilts, volleyball, and the game of snakes. This local culture-based empirical model has been tested in 4 different kindergartens with different subjects and all show success with increased interpersonal and kinenestic intelligence of the child from various indicators. In practice, this model should use textbooks that correspond to the step-steps in the way that are used for optimum results.
\end{abstract}

Keywords: $\quad$ Early Childhood Game, Cultural Values, Interpersonal and Kinesthetic Intelligences

\section{INTRODUCTION}

The results of the study in the first year show that Sondah Games can improve Interpersonal intelligence because in game sondah there are activities that can stimulate early childhood to develop interpersonal intelligence ability because (1) sondah game done by some children so that children are trained to understand social situation and ethics to friends and game opponents, (2) sondah's game also trains children to develop self-awareness of the environment because the game sondah is done in an open environment and uses the materials contained in the environment around early childhood, (3) the game sondah teaches the child to understand problem solving because in this game the child must be able to measure the speed, measure the balance so as not to fall and find a way to get past each box or chart in the game sondah, (4) in a sondah game performed jointly with other children, and children are taught to queue up to play games, to communicate well with friends of the game and to respect one another. Sondah games are held together, the children are taught to listen well, because before the game sondah begins the teacher explains the rules of the game, how to play it and the results to be achieved by the children.

As stated in the first year research proposal, the study has been planned for 2 years of research. Referring to the results of the first year of research above, then the second year of research with the same title that is the game model through local cultural values approach as an effort to improve interpersonal intelligence and kinesthetic 
intelligence of early childhood but with different outcomes that produce models of empirical teaching materials based on local culture for learning interpersonal and kinesthetic intelligence in kindergarten.

The existence of local wisdom is very much its function. As Sartini (2006) argues, that among the functions of local wisdom is functioning for the development of culture and science.

Based on the above background, the main purpose of this research is to find out:

1. Implementation of the conceptual modeling of the game through the approach of cultural values as an effort to improve interpersonal intelligence and early childhood kinesthetic intelligence in West Java Province.

2. The result of the application of conceptual model of the game through the approach of cultural values as an effort to improve interpersonal intelligence and early childhood kinesthetic intelligence in West Java Province.

The intelligence of social relations (Interpersonal Intelligence) is one's ability to understand, interact and pay attention to differences among others, which is the life cycle, mood, temperament, motivation and intentions of each individual (Gardner, 2013: 29). This is in harmony with Yusup that suggests that interpersonal intelligence is the ability of the child to adapt, displaying pleasant attitudes and behaviors for his or her group of people around them through a learning process appropriate to the age level of its development (2004: 122).

According to Gardner (2013: 23) kinesthetic intelligence is the ability of a person to perform physical movements and skills involving all members of the body. In early childhood the process of body movement follows at the age level of their development.

Referring to the Minister of National Education Regulation No. 137 of 2013 which contains learning activities should be contextual, as referred to in paragraph (1) is a learning process related to the demands of the natural and socio-cultural environment.

So teachers should look for teaching materials to improve interpersonal intelligence and early childhood kinesthetic intelligence through cultural values approach, but in reality there are many obstacles and problems that are proven in the initial conditions where there are many games of early childhood that are not spiritually appropriate (KI.1), Social (KI.2), Cognitive (KI.3) and Skills (KI.4), this study aims to find the game model through the approach of cultural values as an effort to improve interpersonal intelligence and kinesthetic intelligence of early childhood group A and group B..

\section{METHOD}

\subsection{Research Method}

Based on the focus of the problem, the objectives, the research subject, and the characteristics of the data, the methodology chosen for this research is Research and Development $(\mathrm{R} \&$ D). Meanwhile, in this research, the R \& D method used refers to the six stages of $\mathrm{R} \& \mathrm{D}$, proposed by Borg and Gall, (1979: 775-776), namely (1) pilot study stage (2) stage of literature study (3) stage of preparation of conceptual model (4) model verification stage (5) stage implementation model (5) evaluation and model development (6) analysis phase of implementation result.

Anderson (1978) in Sudjana (2000: 277) gives guidance on model evaluation and development, which states that the aspects that need to be evaluated are: model preparation; possible model follow-up; the possibility of modifying the model; and findings about model support. Program assessment is a systematic activity for collecting, processing, and presenting data or information as material in decision-making regarding a program.

\subsection{Data Gathering}

Research data which is revealed in this study includes: child language learning, local wisdom, and oral communication of early childhood. These three data were revealed using a special measuring tool developed by the researchers based on constructs that were studied comprehensively in the results of a profound literature study. The data collection instruments developed in this study relate to data collection techniques performed at each stage of the study, namely: (a) interview guidance, (b) observation guidelines, (c) test guides; and (d) documentation study guidelines.

\subsection{Data Analyzing}

Data analysis was conducted throughout the study and refers to the qualitative data analysis model in the opinion of Miles and Huberman (1992: 16) which proposed a data analysis step consisting of three paths: data reduction, data presentation, and conclusion. The same thing was expressed Nasution (1988: 129-130), who put forward the steps of data analysis as follows: 
1. Data Reduction: the data obtained in the field is written/ typed in the form of a detailed description or report. The report prepared then reduced, summarized, selected the main points, focused on the things that are important and looked for the theme.

2. Display Data: data that have been obtained are classified according to the subject matter and made in the form of matrix so as to enable researchers to see the relationship of data with other data.

3. Taking Conclusions and Verification: the researchers make conclusions based on data that has been processed through reduction and display data.

\section{RESULT AND DISCUSSION}

\section{Model 1 (Sondah Game)}

a. Planning

Learning planning development of interpersonal and kinesthetic cultures based on local culture consists of the following steps:

1) Adjust the condition of the class either by a circular shape, letter $\mathrm{U}$, or as per seat in general

2) Provide game media in the form of game sondah

3) Provide observation sheets and progress records of students' abilities

4) Provide attendance list

b. Implementation

The learning steps to develop interpersonal and kinesthetic cultures based on local culture consist of the following steps:

\section{Initial activity}

1) Welcome the arrival of a child with $5 \mathrm{~S}$ (Smile, Greet, Salute, Polite and Well Mannered)

2) Students lined up with accompaniment of songs

3) Pray, and check students' attendance

4) Apperception

5) Start learning according to theme with discussion of communication theme

6) Tell the children about playing sondah using the sondah framework according to the planned plan the previous week

\section{Core activities}

1) Students are divided into 3 groups each group 3-4 people Each group gets a turn in playing sondah
2) The researcher / classroom teacher guides the sondah playing activities

3) Students are guided by the teacher for the implementation of playing sondah

\section{How to play sondah}

First of all write down on the ground 5 squares and there is a so-called mountain that is at the top on the right or left and must be quite large because it is so-called mountain. Then prepare a small broken ceramic then each group choose for example white and black each group choose one of the color Well then if every group have chosen up or down ceramic broken that small, throw not too high, for example the above black colored means the group was first played or it can also be played alone not in groups.

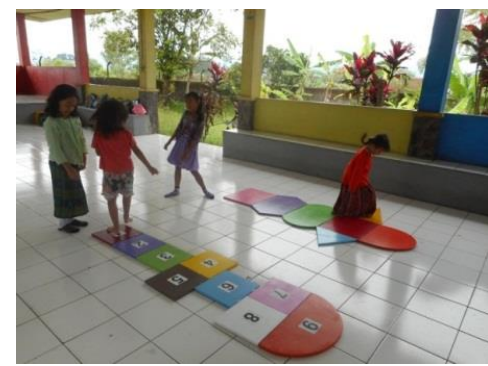

Figure 1. Sondah Game with Mountain Model

Then after that group first play in sequence with a friend of a group, then throw a stone into the first box because you are just playing and we skip the box that there is a small broken ceramic while lifting one foot until it will bring the ceramic and out of the box- the box and so on until the box you have passed all the boxes have been passed and then throw the ceramic, closing the eyes in the last box but in the front, then brought the ceramic and pass each box while lifting one foot and then stop at mountain, then throw out of the box do not go too far and do not get exposed to the line because it means to lose.

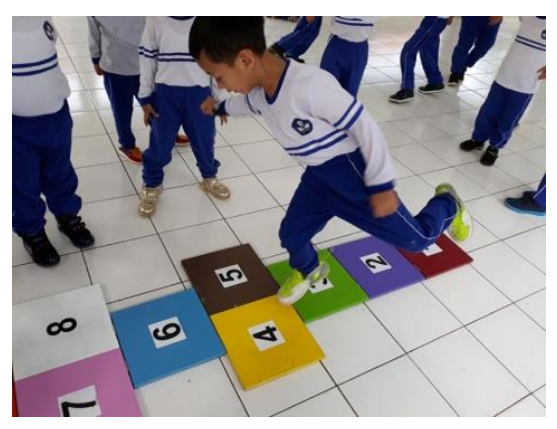

Figure 2. Students are playing sondah 
After that skip all the boxes, the box that you have already pelted the ceramic past then stepped on the ceramics that you threw earlier. That is how to play and to take turns if the group was lost to replace with another group that's how to play until the end and a group get a star

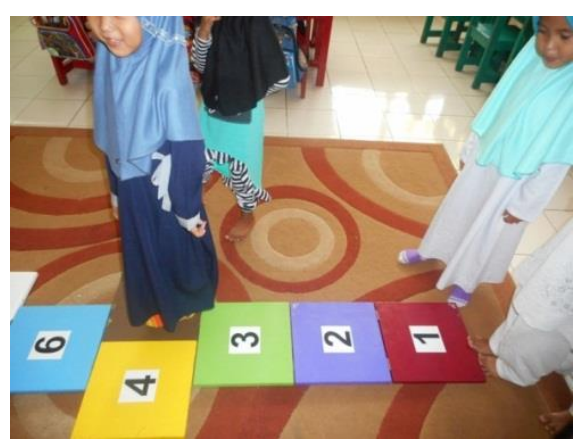

Figure 3. Sondah Game with Plane Model

Model 2 (Oray Orayan Game)

\section{Initial activity}

1) Children line up in the yard (by singing).

2) After marching the children into the classroom, pray and greet (while singing) to start the activity

3) Before discussing about the theme, children read daily prayer recitation i.e. wake up praying.

4) After completion of memorization, the teacher asked the children about yesterday's activities (Apperception).

5) The teacher explains the theme of the day (snake animal) and then explains what the dangers and benefits of snakes while showing snake images in children.

6) Then the teacher explains the activities to be performed today.

\section{Core activities}

1) After finished explaining about the snake the teacher asks the child to work on the package book writing letters (write the letter " $U$ " for the snake).

2) After writing, the teacher asks the child to do LKA (Child Works Sheet) about sequencing the snake image from the largest to the smallest, before the teacher explains in advance how to work it. After the child understands then the child finishes it.

3) After sequencing the child is given LKA snake image to make the work of collage snake image by using stem stem using kale. Teachers prepare paint from food coloring and kale stems to taste.
After the teacher gives an example to the new child the child is asked to try to make as well.

4) After completion of the tasting activities, the activities continued with the activities of playing traditional games oray - orayan.

\section{Game Steps:}

1) The teacher takes the children to the field to play traditional games oray - orayan.

2) Before the play the teacher explains how the snake movement goes and explains the rules of the game.

3) The first 2 teachers became gateways for the snake passing by, the gate was divided to 2,1 teacher became the left gate and 1 teacher became the right gate.

4) Some children are asked to march lengthwise like a snake, then go around the gate made by the teacher while singing the song oray - orayan.

5) When the song finishes sing one of the children will be trapped inside the gate.

6) Then the child will choose to follow (standing behind) the child who stands as the right or left gate (referred to as the mother).

7) After the child chooses the left or right gate, the children return around the gate while singing, repeating until all the children are lined up in their gates.

8) After the gate shapes the snake, then the snake left and right pull each other pull.

9) The group of successful snakes attracts the winner.

10) After the game is over, the teacher evaluates the activities of the child, whether the child can obey the game well or not, what the child has difficulty or not and what impressions after performing the traditional play oray-orayan.

11)After completion of core activities the child rests.

\section{Closure}

1) After the child finishes resting, the child returns to class.

2) The children are asked to sing the song "I'm walking" (about all sorts of animals).

3) Then the teacher reevaluate the activities performed by children for one day at school by asking what activities that have been performed in this day.

4) After the questioning about the one-day activity is over, the children prepare to go home, then pray before returning home, greetings to the teacher. 
Model 3 (Volly Bangkong)

\section{Initial Activities}

Teachers begin activities with children starting with today's news, then the teacher is attending the children. Then the child is invited to sing "march" or other song by dancing, jumping and laughing. After that the children pray before studying, praying smoothly, opening prayers and creeds, then the teacher asks day, date, month and year in the children.

\section{Initial activity of play}

1) The teacher invites the children to make a circle, then the teacher invites children to clap their spirits. Then the teacher gives directions to clap the spirit. Before the start of the game the child was introduced with a game of volly bangkong. Master gave an example of how to make a doll "Bangkong" using a sarong, then the teacher gave an example game Volly Bangkong. After that the teacher makes the game rules upon the children's deal at the time before the game starts

2) The teacher formed a group for this game 1 group consisted of 6 children, 1 group was given media 3 sheets of sarong, after which the child made a doll of bangkong (doll of sarong). After that the children play with enthusiasm and enthusiasm. Teacher watched the children as the game progressed.

3) The teacher asks all children to tidy up the playground. Then, the teacher asks all the children to gather in a circle while singing. Then, the teacher asks all the children to tell their experience after playing. Teachers facilitate all children to dare to talk about their learning experiences. Give the child a time to express his heart with a just.

\section{Closure}

Teachers reward the children who have successfully played the game Volly Bangkong and give encouragement to children who have not been able to successfully play the game volly bangkong. Furthermore, children are welcome to pray and sing before going home.

\subsection{The Achievement of Local Culture-Based Game Models Toward Increased Interpersonal Intelligence of Children}

Based on data analysis of research results, it can be seen that the Interpersonal Intelligence Children before and after the application of the model of learning based on local culture can be summarized in the following table.

Table 1. Improving Interpersonal Intelligence of Children After Implementing Local Culture-Based Learning Process

\begin{tabular}{lll}
\hline Stage of Development & Before (\%) & After (\%) \\
\hline Undevelop (UD) & $0 \%$ & $0 \%$ \\
Starting to Develop (SD) & $32,91 \%$ & $0 \%$ \\
$\begin{array}{l}\text { Developing as Expected } \\
\text { (DE) }\end{array}$ & $67,09 \%$ & $17,72 \%$ \\
$\begin{array}{l}\text { Developed Very Well } \\
\text { (DVW) }\end{array}$ & $0 \%$ & $82,28 \%$ \\
\hline
\end{tabular}

Based on data analysis of research results, it can be seen that Interpersonal Intelligence Children before belonging to very low category. It is seen that out of 79 students, the average score is only 1.98 or in the Starting to Develop (SD) category. The development of students interpersonal intelligence before application of model in the category of Starting to Develop (SD) as many as 53 students or about $67.09 \%$, in the category Developed as Expectations (DE) as many as 26 students or $32.91 \%$ and there is no ability of students in category Developing Very Well (DVW).

Based on the table above, it can be seen that the interpersonal Intelligence of Children after the application of the model of learning based on local culture belong to very good category. It is seen that from 79 students, the average score is only 3.45 or in the category of Developing Very Well (DVW). The development of students interpersonal intelligence after application of the model in the Developing as Expected (DE) category was 14 students or $17.72 \%$, and the students' ability in the Developing Very Well (DVW) category was 65 students or $82.28 \%$, and no student development was found categories Undevelop (UD) and Starting to Develop (SD). 


\subsection{The Achievement of Local Culture-Based Game Models Toward Increasing Kinesthetic Intelligence}

Based on data analysis of research results, it can be seen that kinesthetic intelligence before and after the application of the model of learning based on local culture can be summarized in the following table.

Table 2. Improving Kinesthetic Children Intelligence After Local Culture-Based Learning Process

\begin{tabular}{lll}
\hline Stage of Development & Before (\%) & After (\%) \\
\hline Undevelop (UD) & $0 \%$ & $0 \%$ \\
Starting to Develop (SD) & $51,90 \%$ & $0 \%$ \\
Developing as Expected (DE) & $48,10 \%$ & $15,19 \%$ \\
Developed Very Well (DVW) & $0 \%$ & $84,81 \%$ \\
\hline
\end{tabular}

Based on the table above, it can be seen that the kinesthetic intelligence of children before the application of local culture-based learning model belongs to the low category. It is seen that out of 79 students, the average score is only 2.09 or in the Starting to Develop (SD) category. The level of kinesthetic intelligence of the students before the application of the model in the Starting to Develop (SD) category was 41 students or approximately $51.90 \%$, and the students' ability in Developing as Expected (DE) category was 38 students or about $48.10 \%$ and no students were included Developed Very Well (DVW).

Based on the above table, it can be seen that children kinesthetic intelligence after the application of local culture-based learning model belongs to very good category. It is seen that from 79 students, the average score is reached 3.44 or in the category of Developed Very Well (DVW). The development of students kinesthetic intelligence after applying the model in the Developing as Expected (DE) as many as 12 students or $15.19 \%$ and students' ability in the category of Developed Very Well (DVW) as much as 67 students or about $84.81 \%$, and no student development was found in categories Undevelop (UD) and Starting to Develop (SD).

\section{CONCLUSION}

Based on the analysis and discussion, the researchers took some conclusions of this study as follows:

1. Learning based on local culture typical of West Java able to improve interpersonal and kinesthetic intelligence early childhood. This is demonstrated by the enthusiasm and activity of students who are high enough during the learning activities, with such high activity and enthusiasm, so that the quality of learning becomes better and the interpersonal intelligence and kinestetik early childhood becomes more maximal, the model of local culture-based learning is referred to in this is done by applying the game method in learning in early childhood. The game is implemented in different schools, but in general these three types of games are able to optimize the interpersonal intelligence and early childhood kinesthetic intelligence.

2. It can be seen that the Interpersonal Intelligence of Children after the application of the model of learning based on local culture belong to very good category. It is seen that from 79 students, the average score is only 3.45 or in the category of Developing Very Well (DVW). The development of students 'interpersonal intelligence after application of the model in the Developing as Expected (DE) category was 14 students or $17.72 \%$, and the students' ability in the Developing Very Well (DVW) category was 65 students or $82.28 \%$, and no student development was found categories Undevelop (UD) and Starting to Develop (SD).

3. It can be seen that children kinesthetic intelligence after the application of local culture-based learning model belongs to very good category. It is seen that from 79 students, the average score is reached 3.44 or in the category of Developed Very Well (DVW). The development of students kinesthetic intelligence after applying the model in the Developing as Expected (DE) as many as 12 students or $15.19 \%$ and students' ability in the category of Developed Very Well (DVW) as much as 67 students or about $84.81 \%$, and no student development was found in categories Undevelop (UD) and Starting to Develop (SD). 


\section{REFERENCES}

[1] Amri, Sofan (2013).Pengembangan dan Model Pembelajaran Dalam Kurikulum 2013. Jakarta: Prestasi Pustaka.

[2] Borg \& Gall. (1979). Educational Research an Introduction. New York: Longman,Inc

[3] Gardner, Howard. (2003). Kecerdasan Majemuk. Batam: Interaksar.

[4] Miles, Matthew B dan huberman, A Michael. (1992). Analisis Data Kualitatif. Jakarta: Universitas Indonesia Press

[5] Nasution, S(1988). Metode Penelitian Naturalistik Kualitatif. Bandung: Tarsito
[6] Sudjana. (2000). Metode Statistika. Bandung: Gramedia Pustaka Utama.

[7] Syamsu Yusuf. (2004). Psikologi Perkembangan Anak \& Remaja. Bandung: PT Rosdakarya.

[8] Anderson, James E. (1978). Public Policy Making. New York: Holt, Rinehart and. Winston.

[9] Sartini. 2004. Menggali kearifan lokal nusantara sebuah kajian filsafati. Dalam: Jurnal Filsafat. [Internet]. [dikutip 11 November 2011]; 37(2): 111-120. http://www.searchdocument.com/pdf/1/1/Menggali-Kearifan-

Lokal-Nusantara-Sebuah-Kajian-

Filsafati.html(accessed 20 October

2017) 